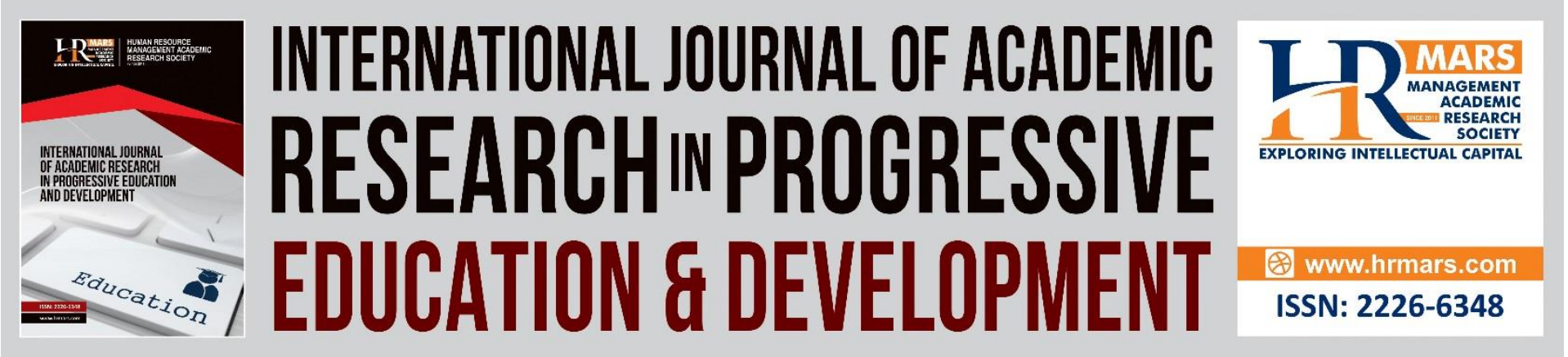

\title{
School Mapping Principles and Compliance Level of Secondary Schools in Lagos State, Nigeria
}

\author{
Gbesoevi, Emmanuel Semako, Ola, Bolanle Adeyemi
}

To Link this Article: http://dx.doi.org/10.6007/IJARPED/v10-i4/11540

DOI:10.6007/IJARPED/v10-i4/11540

Received: 18 September 2021, Revised: 23 October 2021, Accepted: 30 October 2021

Published Online: 10 November 2021

In-Text Citation: (Gbesoevi \& Ola, 2021)

To Cite this Article: Gbesoevi, E. S., \& Ola, B. A. (2021). School Mapping Principles and Compliance Level of Secondary Schools in Lagos State, Nigeria. International Journal of Academic Research in Progressive Education and Development, 10(4), 167-180.

Copyright: (C) 2021 The Author(s)

Published by Human Resource Management Academic Research Society (www.hrmars.com)

This article is published under the Creative Commons Attribution (CC BY 4.0) license. Anyone may reproduce, distribute, translate and create derivative works of this article (for both commercial and non-commercial purposes), subject to full attribution to the original publication and authors. The full terms of this license may be seen at: http://creativecommons.org/licences/by/4.0/legalcode

Vol. $10(4)$ 2021, Pg. 167 - 180

http://hrmars.com/index.php/pages/detail/IJARPED

JOURNAL HOMEPAGE

Full Terms \& Conditions of access and use can be found at http://hrmars.com/index.php/pages/detail/publication-ethics 


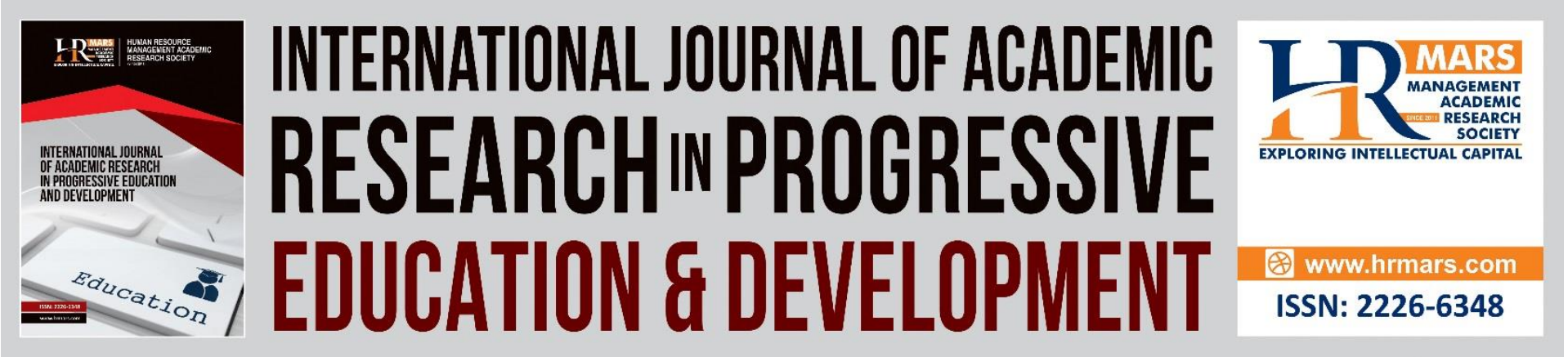

\title{
School Mapping Principles and Compliance Level of Secondary Schools in Lagos State, Nigeria
}

\author{
Gbesoevi, Emmanuel Semako \\ Department of Educational Management, Faculty of Education, Lagos State University, Ojo, \\ Nigeria \\ Email: emmanuel.gbesoevi@lasu.edu.ng \\ Ola, Bolanle Adeyemi \\ Department of Behavioural Medicine Faculty of Clinical Sciences Lagos State University \\ College of Medicine, Ikeja, Nigeria \\ Email: bolanle.ola@lasucom.edu.ng
}

\begin{abstract}
This study examined school mapping principles and compliance level by public and private senior secondary schools in Lagos State, Nigeria. The study population consisted of all senior secondary schools in education district $v$. The simple random sampling technique was used to select 5 respondents from 20 secondary school in Education District V in Lagos State. A research instrument title "School Mapping Principle and Compliance Level Checklist (SMPCLC) was used to gather data. Face and content validity was used to validate the instrument and was found reliable through test-re-test technique at 0.75 . Three research questions were raised and answered. Data collected were analysed through simple percentage, means and standard deviation. The findings of the study are that most of the schools established are not in accordance with the stated guidelines for establishing schools, and most of the school owners do not comply with the guidelines for establishing schools in Lagos state. It is therefore recommended that strict attention should be placed on school mapping principles and its usefulness in creating a conducive atmosphere that will enhance effective administration and productive academic activity. More so, the Lagos State Government should revoke, suspend and withdraw an approval granted if the schools do not operate according to the prescribe guidelines.
\end{abstract}

Keywords: School Mapping, Principle, Compliance Level and Secondary Schools

\section{Introduction}

The twin-advantage of education for personal and national development are sufficient to make it available to all and sundry. As a weapon to reducing illiteracy in developing countries, the question of easy accessibility to people is not debatable. Hence, this study examined school mapping principles and compliance level in an effort to guaranteeing opening doors to education to everybody while not losing sight of the challenges that might make this mission 
impossible in the process. Firstly, education is a major key to any surviving civil society. Education is a powerful instrument for development and economic prosperity through the development of the latent capacities in man, equipping the man with relevant skills, knowledge, attitude and capacities necessary for a productive economic life. One cannot imagine the development of a nation when the supposed key actors (peoples) of the development are predominantly illiterates, underdeveloped and poor.

There are various definitions of school mapping as there are authors in educational planning with all of them converging at a point. Yusuf and Akinniranye (2011), for instance, defined school mapping as the process of estimating and diagnosing school requirement and identifying the ideal communities and sites where new schools are to be located and where additional educational resources are to be provided. According to Akpakwu (2012), school mapping is a set of techniques and procedures used in identifying future educational needs that are to be located in a particular community or geographical area. Sabir (2013) sees school mapping as a dynamic process of identifying logically and systematically the communities and sites where educational facilities provided in a plan are to be located. Oluchukwu (1998) defines school mapping as the concepts of diagnostic stock-taking of educational system with a specific aim of determining what types and stock of resources and facilities that are needed in the future and how best existing facilities can be put into optimal use in view of the scarcity of resources. In the words of Ajayi et al (2013), school mapping is expressed as involving applying skills and thought processes and analytic techniques to find out what additional facilities are required for education and what type of future a society may have. Olaniyonu and Gbenu (2015) sees school mapping as a sequence of activities directed towards the achievement of effective and efficient implantation of the goal of the educational system through appropriate location and spatial distribution of school, taking into consideration, the demographical, pedagogical, economic, geographical, social, administrative, political and man power factors.

From the plethora of definitions therefore, school mapping can be perceived as the continuous, systematic and rational process of setting and rationalising educational facilities such as building structure, classroom, and teacher and to ensure they are provided in a way that the set educational goals are realised. School mapping is basically all about school network which is dynamic in response to the dynamic nature of the environment it served. School mapping is an essential strategy for realising educational goals and objectives According to, Kafunwa and Herman, (2012), school mapping requires that educational facilities are systematically and rationally located such that the age group within the population for what it is targeted may use the facilities to their maximum advantage. School mapping is a set of techniques and procedures used to estimate future education requirements at local level and work out what needs to be done to meet them. In that sense, school mapping is a micro-planning exercise, with the specificity that it seeks a better match between the supply of, and demand for, education. Do not confuse school mapping with a simple "atlas" merely showing the location of schools. Showing where schools are located, though very useful, is but the first stage of school mapping. Unlike an ordinary map that by its very nature is static, school mapping gives a dynamic and prospective vision of how the education service should look in the future, showing its buildings, teachers, and facilities, to enable the implementation of education policies. School Mapping originated in France in the year 1963 when the government of France decided to extend the period of compulsory schooling to the age 16 which required the establishment of a large number of new schools. It quickly became apparent that the ministry of education could not itself plan the location of 
all the new schools nor did the regional offices have the methodological means to decode what type of schools were needed and where a collection of circulars, regulations, standards and procedures were prepared at that time and given the name "the school map"

Essentially, school mapping are purposed to ensure that schools are located at a suitable site for both children and members of the community; ensure that children attend school at a considerable short distance, with attention paid to catchment factors which refer to area that will benefit from the school; to ensure adequate utilisation of educational resources; to improve the quality of education; reveal the extent of under- or- over-utilisation of existing educational facilities and also to provide the learning needs of the society among others. Also, according to Ifebuzor, Nkemakolam and Akintoye (2015), the main purpose of school mapping is to work out a programme which will enhance the expansion of educational facilities, taking into consideration the regional inequalities and economic requirements, such as provision of vocational and technical components of primary and secondary schools.

The scope of school mapping in terms of application consists of the following: educationally backward areas, which are characterised by low enrolment and participation rate, lack of facilities and are usually found in rural areas educationally advanced area and areas that need reforms. Problems confronting these areas include qualified teachers refusal to accept appointment in isolated villages, villager's refusal to send their children to school because they are dependent on them for help, multi-grade classroom being poorly run often and ineffectively among others. Educationally advanced areas are usually urban centers that are characterized by a wide spread of primary and secondary schools and facilities, high enrollments, overcrowded classrooms, high transition rates and low drop-out rates. School mapping in these areas will be limited to rectifying the educational facilities, taking into account rural to rural, urban to urban and rural to urban population movements. Lastly, areas that need reforms would need a reorganization taking into account problematic areas. For instance, in reforming an educational system like 6-3-3-4/9-3-4, school mapping can play the following roles: can help the child to see learning as an integrated whole; can develop school complexes to help in solving problems of facilities and recourses; it help to retain teachers who will help in the reform; it will help to rationalize school network and to help in in identifying the financial implication involved in the reform. As a function, school mapping helps to determine how school may be reconverted and how premises may be relocated geographically so as to adjust supply to the education system new characteristics as laid down in the programme. It ensures that all educational supplies are made with the least cost with the aim of ensuring educational goals.

Equally too, the functions of school mapping are summarised by Adaja and Osagie (2015), include the following:

1. To create a conducive condition for achieving universal primary and secondary education.

2. To increase access for the traditionally under-represented socio-economic groups, which in most cases are the females.

3. To promote the equitable distribution of educational benefits within and between different regions and populations.

4. To improve the quality of educational efforts

5. To optimise in the most efficient way the use of existing capital, human and financial resources.

6. To organise, coordinate and rationalise efforts at technical, vocational and post-secondary education 
The major role of school mapping is to set up rational school network to meet educational demand of the society. This role comes into play majorly when large-scale significant expansion of an educational system takes place. The major indicators of school mapping includes population/demographic data, data on educational planning, data on classes, data on teaching and non-teaching staff, data on students, data on school building and equipment and data on educational expenditure

Meanwhile, compliance to the school mapping ensures that all children of school age are given education in order to ensure beyond the end of compulsory education within the limit of available resources (Manga \& Nakazalle 2015).

Efforts have been made to ensure school mapping principles are complied with as reported in various literatures. International institute for educational planning over the years have put in lot of synthesized measures to ensure school mapping compliance.

Meanwhile, Oyebade (2009) and Akpakwu (2012) have summarised the objectives of school mapping as follows:

1. To promote accessibility and equality of educational opportunities for all.

2. To make sure that there is equity in the distribution of educational facilities to communities where they are needed and utilized to the highest advantage.

3. To ensure safety and convenience to and from school.

4. To ensure future possibility of expansion in terms of land size and increase in school enrolment.

5. To ensure that there is cost effectiveness and efficiency by improving the ratio between cost and performance.

6. To avoid over-localization or over-concentration of schools in certain areas while other areas are lacking.

The government of the federal republic of Nigeria NPE (2014) stated the broad aims of secondary education within the overall national objective to include:

i. Preparation for useful living within the society and

ii. Preparation for higher education

Every secondary school should strive hard to meet the expectation of the society through the achievement of the stated objectives. It is in view of this that a research study on school mapping principles and compliance level by secondary schools in Lagos State, Education District $V$ is a necessity.

The most reported problem is that most excelling learners tend to emerge from private schools in the modem academic dispensation in Nigeria. It has been observed that most school in Lagos State are facing challenges of over-utilisation, congestion and indiscipline as a result of unimaginably high student enrolment and over-stretched resources, attainment of education objectives may not be guaranteed in an area where the building structure, physical facilities and classroom are not strategically located or situated. Location of school is very vital to every educational manager, administrators, owners and other stakeholders. The government in a bid to better the lots of her citizenry day in day out thinks about how to bring education to the people. Communities and groups also consider the noble venture of educating their subjects.

This usually translates to the establishment of government schools, community schools, mission schools and privately owned secondary schools. Whoever the owner maybe, its location is always very vital and instrumental to the achievement of the ultimate goals of education. 
Ntukidem (1992) opined that school location should take into consideration the problem of distraction in the vicinity, such as the noise of industrial establishment and criteria highways. The fact here is that school sitting should be done to avoid noisy environment so as not to distort teaching learning process.

Haphazard location of schools as observed by school mapping experts has great impact on the character of student. Students who go to school at far distance from their homes shows high level of training, lateness to school (sometimes) and other anti-social behavior and these greatly affect academic performance of student in school. Schools in Lagos State with high population encourage act of indiscipline, disobedience to school rules and regulations while schools that are not thickly populated but far from homes also promote social vices and indiscipline in school.

Lastly, National Policy on Education (2014) stated that it is through efficient location of school that education can be made meaningful and accessible to the Nigerian child thereby bringing into reality government desire on education.

The purpose of this study were to:

- examine if secondary school owners comply with the guidelines of school mapping principles in Education District V of Lagos State.

- investigate if secondary school location has any significant effect on student's academic performance in Education District V of Lagos State

- investigate if secondary schools have the standard physical facilities as required for school mapping principles in Education District $\mathrm{V}$

It is believed that this study is significant in education generally and specifically provides more information on school mapping principles and compliance level in secondary schools in Education District IV of Lagos State.

In line with some identified problems, this study sought to find answers to the following

\section{Research Questions}

1. Do school owners comply with the guidelines of school mapping principles?

2. Does school location have any significant effect on student's academic performance?

3. Do schools have the standard physical facilities as required for school mapping principles?

\section{Methodology}

The descriptive survey design was used in this study. The population for this study comprised of all public and private senior secondary school in Education District $\mathrm{V}$ of Lagos State. The simple random sampling technique was used to select five teachers each from 20 secondary schools in Educational District $V$ of Lagos State making a total of 100 respondents. A structured checklist titled "School Mapping Principles and Compliance Level Checklist (SMPCLC)" was used in the study for data collection to seek respondents opinion about school mapping principles and compliance level by public and private senior secondary schools selected. The checklist comprised Section A and B. Section " $A$ " deals with demographic data of the respondent while Section " $B$ " comprises of 20 items, which are related to the generated research questions. The instrument was validated through face and content validity while a test retest reliability method was used to test the reliability of the instrument with the coefficient at 0.78 . The completed checklist was collected, coded and analysed using frequency table, mean, standard deviation and using Statistical Package Social Science (SPSS) Version 20 
DEVELOPMENT

Vol. 10, No. 4, 2021, E-ISSN: 2226-6348 @ 2021 HRMARS

\section{Results/Findings}

Research Question 1

Does School Owners Comply with the Guidelines of School Mapping Principles? (Item 1 - 3)

Summary of the data obtained and their frequency for item 1 to 3 that discusses the first research question "Does Schools Owners Comply with the Guidelines of School Mapping Principles? "As presented in Tables 1, while the mean and standard deviation of schools that complied with the guidelines of school mapping principles is presented in Table 1

Table 1: Does School Owners Comply with the Guidelines of School Mapping Principles?

\begin{tabular}{llllll}
\hline $\begin{array}{l}\text { Compliance Level } \\
\text { of Schools }\end{array}$ & $\begin{array}{l}\text { Comply } \\
(\mathbf{n})\end{array}$ & $\begin{array}{l}\text { Non-comply \% } \\
(\mathbf{n})\end{array}$ & $\begin{array}{l}\text { Valid } \\
\text { (listwise) }\end{array}$ & $\begin{array}{l}\text { Mean } \\
\text { Error }\end{array}$ & $\begin{array}{l}\text { Std. } \\
\text { Deviation }\end{array}$ \\
\hline $\begin{array}{l}\text { Schools with } 72 \\
\text { standard Land Size }\end{array}$ & 18 & & & \\
Schools with Less 85 & 15 & & & \\
than 35 Students in \\
a Class
\end{tabular}

Summary of the data obtained and their percentage for questions 1 to 3 that discusses the first research question "Does Schools Owners Comply with the Guidelines of School Mapping Principles? "As presented in Tables 1 to 3, while the mean and standard deviation of schools that complied with the guidelines of school mapping principles is presented in Table 1.

As shown in Table 1, only $72 \%$ respondents agree that schools in the study area meet up with standard plot of land size ( 2 plots minimum) while $18 \%$ respondents do not agree that schools meet up the standard of plot of land size for schools, 15\% respondents do not agree that schools adhere to the standard number of students in a class (not more than 35 students), while $85 \%$ respondents agree that schools have more than 35 students in class, $69 \%$ respondents agreed that schools have certificate of occupancy while $31 \%$ respondents do not agree that schools have certificate of occupancy. This implies that, an overall $63 \%$ respondent of the studied schools do not comply with the guidelines of school mapping principles while $37 \%$ respondent agreed that schools complied with the guide line of school mapping principle. Hence, the mean of the schools that comply with the principle is 0.37 while that standard deviation is 0.49 . This means that majority of the schools do not comply with the guidelines of school mapping principles, hence to the first research question (Does Schools Owners Comply with the Guidelines of School Mapping Principles?) is No, and they don't. 
INTERNATIONAL JOURNAL OF ACADEMIC RESEARCH IN PROGRESSIVE EDUCATION AND

DEVELOPMENT

Vol. 10, No. 4, 2021, E-ISSN: 2226-6348 @ 2021 HRMARS

\section{Research Question 2}

Does School Location have any significant effect on the Student's Academic Performance? (Item 4-6)

Table 2: Does School Location Affects the Student's Academic Performance? (Research Question 2)

\begin{tabular}{|c|c|c|c|c|c|c|c|}
\hline $\begin{array}{l}\text { Compliance Level } \\
\text { of Schools }\end{array}$ & Agree & $\begin{array}{l}\text { Disagree } \\
\text { (n) }\end{array}$ & $\%$ & $\begin{array}{l}\text { Valid N } \\
\text { (listwise) }\end{array}$ & Mean & $\begin{array}{l}\text { Std } \\
\text { Error }\end{array}$ & $\begin{array}{l}\text { Std. } \\
\text { Deviation }\end{array}$ \\
\hline $\begin{array}{l}\text { Students Living } \\
\text { Closer to School } \\
\text { Out performing } \\
\text { those Living Farther }\end{array}$ & 61 & 39 & & & & & \\
\hline $\begin{array}{l}\text { Student Residential } \\
\text { areas will affect } \\
\text { their academic } \\
\text { performance }\end{array}$ & 73 & 27 & & & & & \\
\hline $\begin{array}{l}\text { School Located } \\
\text { nearer to a motor } \\
\text { park affect the } \\
\text { academic } \\
\text { performance of the } \\
\text { students }\end{array}$ & 71 & 29 & & & & & \\
\hline $\begin{array}{l}\text { School Location } \\
\text { affects the } \\
\text { Student's } \\
\text { Academic } \\
\text { Performance }\end{array}$ & 79 & 21 & & 100 & .80 & 0.74 & .407 \\
\hline
\end{tabular}

Table 2 shows that $61 \%$ of the respondents agrees that students living close to school outperforms those living farther while $39 \%$ of the respondent do not agree that students living close to school do not outperforms those living farther, $73 \%$ respondents agrees that the distance of the school to student residential areas will affect their academic performance while $27 \%$ respondents disagree that the distance of the school to student residential areas will not affect their academic performance, $77 \%$ respondents agrees that school located nearer to a motor park affects the academic performance of the students while $23 \%$ respondents disagree that school located nearer to motor park do not affects the academic performance, $79 \%$ of the respondents is of the opinion that school location affects the student's academic performance while $21 \%$ respondents is of the opinion that school location do not affect student academic performance. Therefore, the answers to the second research question "Does School Location have any significant effect on the Student's Academic Performance? Is Yes, it does. 
INTERNATIONAL JOURNAL OF ACADEMIC RESEARCH IN PROGRESSIVE EDUCATION AND

DEVELOPMENT

Vol. 10, No. 4, 2021, E-ISSN: 2226-6348 @ 2021 HRMARS

\section{Research Question 3}

Do Schools have the Standard Physical Facilities as Required for School Mapping Principles? (Questions 7-20)

Summary of the obtained data and the frequency for questions 7 to 20 , which discusses the third research question "Do School have the Standard Physical Facilities as Required for School Mapping Principles?"

Table 3: Do Schools have the Standard Physical Facilities as Required for School Mapping Principles? (Questions 7 - 20)

\begin{tabular}{|c|c|c|c|c|c|c|}
\hline $\begin{array}{l}\text { Compliance Level of } \\
\text { Schools }\end{array}$ & $\begin{array}{l}\text { Comply \% } \\
\text { (n) }\end{array}$ & $\begin{array}{l}\text { Non-comply } \\
\%(n)\end{array}$ & $\begin{array}{l}\text { Valid N } \\
\text { (listwise) } \\
\text { No }\end{array}$ & Mean & $\begin{array}{l}\text { Std } \\
\text { Error }\end{array}$ & $\begin{array}{l}\text { Std. } \\
\text { Deviation }\end{array}$ \\
\hline $\begin{array}{lr}\text { Schools With } & \text { Well } \\
\text { Resourced } & \text { And } \\
\text { Ventilated } & \text { Physics } \\
\text { Laboratory } & \end{array}$ & 32 & 68 & & & & \\
\hline $\begin{array}{l}\text { Schools With Well } \\
\text { Resourced and } \\
\text { Ventilated Chemistry } \\
\text { Laboratory }\end{array}$ & 32 & 68 & & & & \\
\hline $\begin{array}{l}\text { Schools With Well } \\
\text { Resourced Biology } \\
\text { Laboratory }\end{array}$ & 32 & 68 & & & & \\
\hline $\begin{array}{l}\text { Schools with } \\
\text { Functional ICT Room }\end{array}$ & 39 & 61 & & & & \\
\hline $\begin{array}{l}\text { Schools with well } \\
\text { Equipped Library }\end{array}$ & 21 & 79 & & & & \\
\hline $\begin{array}{l}\text { Schools With Well- } \\
\text { equipped functional } \\
\text { sickbay }\end{array}$ & 32 & 68 & & & & \\
\hline Schools with Fence & 100 & 0 & & & & \\
\hline $\begin{array}{l}\text { Schools with } \\
\text { Functional/Interactive } \\
\text { Whiteboard in Classes }\end{array}$ & 93 & 7 & & & & \\
\hline $\begin{array}{l}\text { Schools with Eight (8) } \\
\text { water Closets }\end{array}$ & 59 & 41 & & & & \\
\hline
\end{tabular}




\section{DEVELOPMENT}

Vol. 10, No. 4, 2021, E-ISSN: 2226-6348 @ 2021 HRMARS

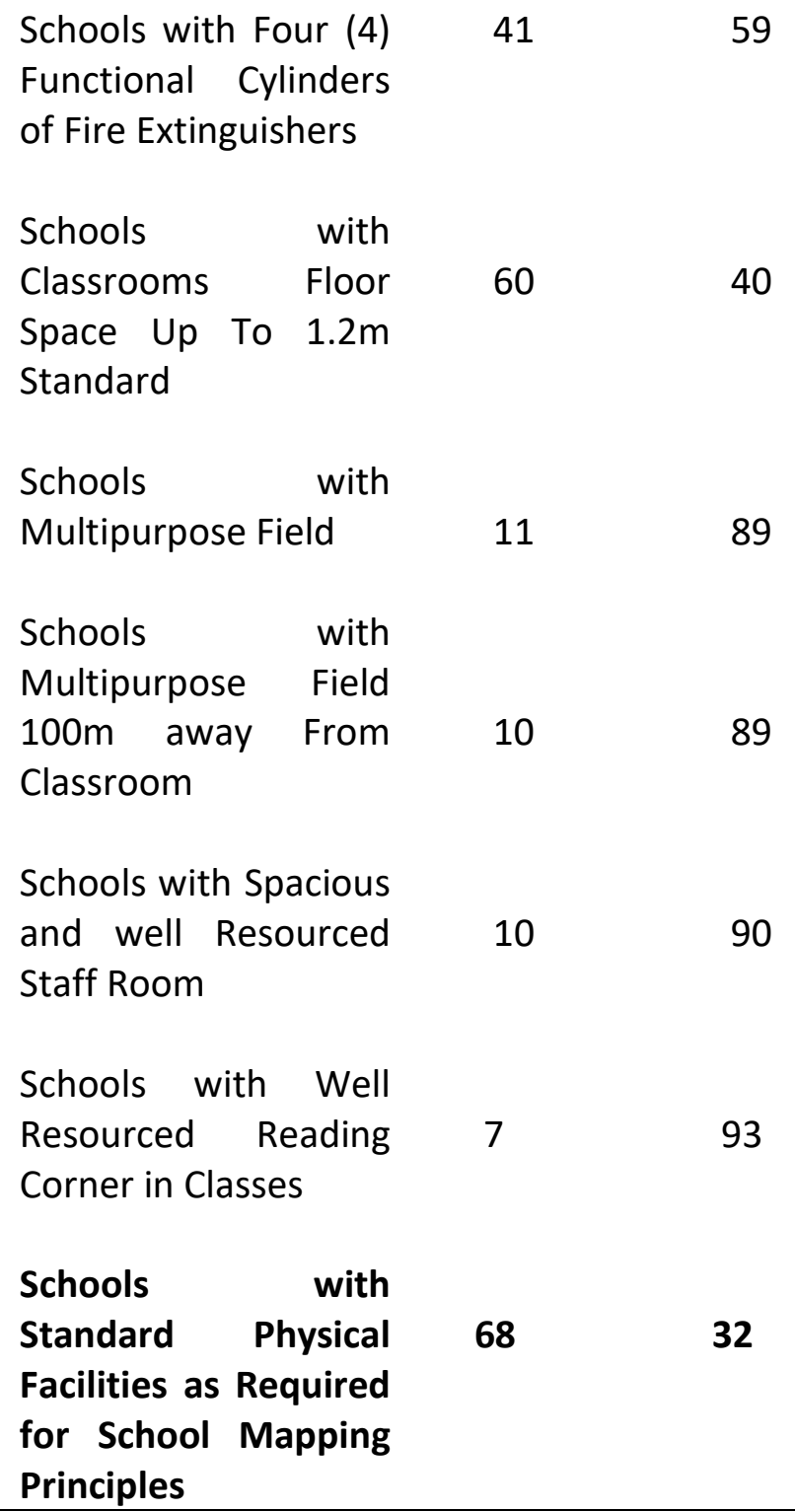

59

40

89

Table 3 shows that, 68\% respondents agrees that schools under study do not have wellresourced and ventilated physics laboratory while $32 \%$ respondents agrees that schools have a well-ventilated physic laboratory, $68 \%$ respondents agrees that schools under study do not have well-resourced and ventilated chemistry laboratory while $32 \%$ respondents agree that schools have a well-ventilated chemistry laboratory, $68 \%$ respondents agrees that school under study do not have well-resourced and ventilated biology laboratory while $32 \%$ respondents agree that schools have a well-ventilated physics laboratory, $61 \%$ respondents agrees that schools do not have a functional ICT room while $39 \%$ agrees that schools have a functional ICT room, $61 \%$ respondents agrees that school do not have a well-equipped library while $39 \%$ agrees that school have well-equipped library, $68 \%$ respondents agrees that schools do not have well-equipped functional sickbay while $32 \%$ respondents agree that schools have a well-equipped functional sickbay, school has a good fencing perimeter of $100 \%, 7 \%$ respondents agrees that schools do not have a standard whiteboard, while 93\% respondents agrees that school have a functional and standard whiteboard, 7\% respondents agrees that schools do not have a standard whiteboard, while $93 \%$ respondents agrees that school have a functional and standard whiteboard, 59\% respondents agrees that schools do 
not have functional cylinders of fire extinguishers while $41 \%$ respondents shows that school do have functional cylinder fire extinguishers, $40 \%$ respondents agrees that schools do not have classrooms floor space up to $1.2 \mathrm{~m}$ standard, while $60 \%$ respondents agrees that schools do have classroom floors space up to $1.2 \mathrm{~m}$ standard, $50 \%$ respondents agrees that schools do not have multipurpose field, while $50 \%$ respondents agrees that do have multipurpose field, $89 \%$ respondents agrees that schools do not have multipurpose field $100 \mathrm{~m}$ away from classrooms while $11 \%$ respondents agrees that schools have multipurpose field $100 \mathrm{~m}$ away from classroom, $90 \%$ respondents agree that schools do not have a spacious and wellresourced staff room while $10 \%$ respondents agree that school do have a well-resourced staff room, 93\% respondents agrees that school do not have a well-resourced reading corner classes while $7 \%$ agrees that schools have a well-resourced reading corner. Thus, $68 \%$ respondents agrees that schools do not possess standard physical facilities as required for school mapping principles while 32\% respondents agrees that schools possess standard physical facilities as require for school mapping principles. The mean and standard deviation of the schools with standard physical facilities as required for school mapping principles is 0.37 and 0.485 respectively.

Therefore, the answer to the third research question (Do School have the Standard Physical Facilities as Required for School Mapping Principles?) is No, they don't.

In summary, the findings of this study show that school mapping principles are not complied with. Most schools in Education District $V$ of Lagos State are not established in accordance with the state guidelines for establishing a school. From this study, it is gleaned that: school owners especially the private schools do not comply with the guidelines of school mapping principles; school locations have significant effect on the student's academic performance; most schools do not have the required standard physical facilities as required for school mapping.

\section{Discussion of Findings}

The above result is supported by the report of Kreitner, (2016) to Lagos State Ministry of Education which states that there are too many unregistered and yet to be approved schools in the state and which most of their activities do not conform with the guidelines for establishing schools in the state. Also our findings are in line with those of Obanya, (2011), Lenshie (2013), Cecilia \& Osagi, (2013), who posited that government in power indulges in the opening and running of many educational institutions, even when they are least prepared to do so, without due regards to school mapping guideline, principle, equity and rationality. Also the findings are in consonance with findings of Adamma (2015) that learning institutions were located haphazardly without due regards to school mapping principles and guidelines and that without school mapping, schools would be haphazardly located without consideration for the needs of the populace which has resulted into many inadequacies in the school system such as lopsided location of learning establishment, disparities in access to education, overlocation and under-location of educational facilities.

The findings also corroborate Ibitoye (2018) and Irvine Unified School District (2013) findings with the opinion that school locations are known to influence the student learning through quality teaching staff, class size and availability of infrastructure. The location of school has been an indispensable aspect of any effective school planning. This is so because the location that can influence the type of school to be built and quality and quantity of buildings. The study also conforms to the findings of Johnson (1998) that school location, relief, drainage, soil vegetation and features as the examined factors of geographical location of schools which 
he opined may collectively or singularity influence the students' academic performance. Our finding also aligns with the findings of Bosede (2010) that location of school influences students" academic achievement in some areas. But the finding contradicts that of Considine and Zappala (2002) that school location does not significantly predict outcomes in school performance and that of Alokan (2010) who in his studies on the influence of location on relationship between students" problem and academic performance affirmed that location does not affect the negative relationship between student problems and academic performance. However, our finding supports majority of previous studies that school location affects the academic performance of students.

Also, the finding of this study is in consonance with the finding of Afework (2014) stating that availability of school facilities and their effects on the quality of education in government schools of Harari Regional, Ethiopia showing that the availability of school facilities were unavailable, less in quantity and quality that created a great challenge on teaching and learning activities that in turn had a negative impact on the improvement of the quality of education. Similarly, Ekundayo (2012), studied school facilities as correlates of students' achievement in the affective and psychomotor domains of learning which revealed that the schools' physical facilities were not all that adequate. The study further revealed that the students achieved well when educational facilities are made available. Corroborating this finding is Bizimana and Orodho (2014), who reported on teaching and learning resource availability and teachers' effective classroom management as well as content delivery in schools in Rwanda and they argued that availabilities of educational facilities to teaching and learning resources in the study locale was insufficient, hence compromising the effectiveness of classroom management and content delivery

\section{Conclusions}

The major conclusion of this study is that there exist imbalances between school mapping principles and guidelines and compliance level by school owners. There are locations in the block where schooling physical facilities inadequately provided.

Equally too, over-politicisation of the process, lack of or poor policy framework guidelines, non-involvement of educational planners, no site feasibility study conducted, lack of proper assessment from the Ministry of Education, lack of technical facilities like Global Positioning System (GPS) and poor funding are the factors militating against effective school mapping principles system in Lagos State.

Lastly, overcrowded classrooms, with most schools especially the public schools have been linked to increased levels of aggression in students. The overcrowded classrooms are also associated with decreased levels of student engagement and therefore, decreased level of learning.

\section{Recommendations}

On the premise of the findings and conclusion, the following recommendations were made:

1. Adequate and stringent policy should be put in place for schools owners to comply with school mapping principle. Hence schools that default should be penalized. Consequently, more professionals in school mapping should be trained and adequate mapping equipment be provided.

2. It is very obvious that the location of a school and the facilities therein have a great role to play in the actualization of the objectives of the school. Educational policy makers, educational administrators and other stakeholder in education should realize 
that the location and the facilities of a school determine the worth of the school. Hence schools should be located in areas not far from the citizens they intend to cater for.

3. Utmost concretizations and attention should be placed on school mapping with provision of well standardized modern school facilities, well equipped laboratories and good school climate so as to create a conducive atmosphere that will enhance effective administration and a defined academic activity in the interest of the student, teachers and the community at large.

4. Classrooms with ample space are more conducive to providing appropriate learning environment for students and associated with increased student's engagement and learning

5. The Lagos State Government should revoke, suspend and withdraw an approval granted if the school does not operate according to the stipulated guidelines

\section{Reference}

Adaja, C. F. \& Osagie, R. O. (2015). Politics of school mapping and facility provision in higher education in Nigeria. In N. M. Abraham, D. O. Durosaro, M. Nwadiani, G. G. Kpee, J. E. Okon and I. A. Odiba, Politics of education and national development in Nigeria (pp,8186). Port Harcourt: University of Port Harcourt Press.

Adamma, E. S. (2015). Politics of school mapping and facilities provision in secondary schools in Nigeria. Paper presented at the $34^{\text {th }}$ NAEAP National Conference held in University of Benin, Benin City. $6^{\text {th }}-9^{\text {th }}$ October.

Afework, T. H. (2014). The Availability of School Facilities and Their Effects on the Quality of Education in Government Primary Schools of Harari Regional State and East Hararghe Zone, Ethiopia. Middle Eastern \& African Journal of Educational Research, 11, 59-71

Ajayi, I. A., Ekundayo, H. T., \& Arogundade, B. B. (2013). Demographic Analysis in Educational Management. Lagos: Atlantic Associated Publishers

Akpakwu, S. O. (2012). Principles and techniques of education. Makurdi: Destiny ventures.

Alokan, F. B. (2010). Influence of sex and location on relationship between students a. problems and academic performance. The social sciences (TSS), 5(4), 340-345

Bizimana, B., \& Orodho, J. A. (2014). Teaching and Learning Resource Availability and Teachers' Effective Classroom Management and Content Delivery in Secondary Schools in Huye District, Rwanda. Journal of Education and Practice, 5(9), 111-122.

Bosede, A. F. (2010). Influence of sex and location on relationship between students a. problems and academic performance. The social science, 5(4), 340-345.

Considine, G., \& Zappala, G. (2002). The influence of social Economic disadvantage in the a. academic performance of school students in Australia. Journal of Sociology, 38, 127148.

Ekundayo, H. T. (2012). School facilities as correlates of students' achievement in the affective and psychomotor domains of learning. European Scientific Journal, 8(6), 208-215.

Federal Republic of Nigeria. (2014). National Policy on Education Lagos: NERDC Press.

Ibitoye S. A. (2018). Secondary School Mapping and Physical Resource Management as correlates of School effectiveness in Ekiti State. Nigeria. Unpublished Ph.D Thesis, University of llorin

Ifebuzor, L., Mkemakolam, A. P., \& Akintoye, M. L. (2015). Politics of school mapping and facility provision in public secondary schools in Nigeria. In N. M. Abraham, D. O. Durosaro, M. Nwadiani, G. G. Kpee, J. E. Okon and I. A. Odiba, Politics of education and 
national development in Nigeria (pp 274-282). Port Harcourt: University of Port Harcourt Press.

Irvine Unified School District. (2013). Board policy: School location and facility planning. http://www.lusd.org/bdpolicy/polieis/7100

Johnson, A. B. (1998) School Mapping and resources supply as correlates of students Academic Achievement in Kwara State Secondary Schools. Unpublished Ph.D Thesis, University of Ibadan.

Kaufman, R., \& Herman, J. (2012). Educational Planning: Strategic, Tactical, and Operational. Lanhalm MD: Rowman \& Littlefield Education.

Kreitner, R. (2002). Management (seventh edition). India: AITBS Publishers and Distributions. Lagos State Ministry of Education (2016) Revised Edition, Alausa, Ikeja

Lenshie, N. E. (2013). Politicisation of Education in Nigeria: Implications for National Transformation. Global Journal of Human Social Science Political Science. 13 (5) : 22 33

Madumere, S. C. (2000). School Mapping as a tool for institutional rationalization of network of schools. Joja educational research and publishers Itd.Management. Lagos: Atlantic Associated Publisher

Manga, S. D., \& Nakazalle, N. U. (2015). Politics of school mapping in Nigeria: Implications for school managers. In N. M. Abraham, D. O. Durosaro, M. Nwadiani, G. G. Kpee, J. E. Okon and I. A. Odiba, Politics of education and national development in Nigeria (pp423-430). Port Harcourt: University of Port Harcourt Press.

Ntukidem, P. J. (1992) School plants management. In Adeboyeje, RA (Ed) Fundamentals of education for colleges and universities. Okitipupa: ADADEB Nigerian Enterprises.

Obanya. (2011) Politics and the Dilemma of Meaningful Access to Education: The Nigerian Story: Create Pathways to Access Research Monograph No. 56.

Olaniyonu, S. O. A., \& Gbenu J. P. (2015): Demographic Analysis and School Mapping: The heartbeats of effective school location. Ogun State: Laideb Ventures.

Oluchukwu, E. E. (2000). School mapping and rationalization of institutional network: Criteria for optimal utilization in a period of educational crisis. Studies in educational planning and administration (SEPA). Journal of the national Institute for educational planning and administration (NIEPA) 1 (1).

Oyebade, S. A. (2009). School mapping and facilities analysis. In J. B. Babalola and A. O. Ayeni, Educational management: Theories and tasks. Lagos: Macmillan Nigeria Publishers

Sabir, M. M. (2013). School mapping in the light of educational reforms in Pakistan. American Journal of Research, 1(8), 279-282. Yusuf, M. A. \& Akinniranye, O. I. (2011). Towards optional utilization of school facilities in secondary schools. JORIND 9(1), 167-171.

Yusuf, M. A., \& Akinniranye, O. I. (2011). Towards optional utilization of school facilities in secondary schools. JORIND 9(1), 167-171. 